\title{
Chorus Chiefs' Views About Chorists' Lifelong Learning Skills
}

\author{
Tuğçe Kaynak \\ Correspondence: Tuğçe Kaynak, Dr.Lecturer, Kırıkkale Universty, Fine Arts Faculty, Music Department, \\ Kırıkkale,7145, Turkey.
}

Received: October 18, 2018

doi:10.11114/jets.v6i11a.3814

\author{
Accepted: October 24, 2018 \\ Online Published: November 29, 2018 \\ URL: https://doi.org/10.11114/jets.v6i11a.3814
}

\begin{abstract}
An individual with lifelong learning skills is always one step ahead. Individuals develop themselves in the branches of art people are interested in in order to be able to live and develop themselves in a social environment and in different cultural environments. Individuals develop themselves on individual instrument training or collective performance such as choral education in the types of music they are interested in. In the study, the opinions of 5 choirs were taken about the progress of the individuals who were between 55 and 70 years old. A semi-structured interview form has been applied to 5 choir chiefs to determine the effect of chorus work on the social and personal development processes of the chorus work that the chorists participated in this process. Each data obtained as a result of the interview is analyzed by content analysis method. Codes are converted into numerical values and are interpreted. As a result of the research, the positive effects of chorus workshops on social and personal development of the individuals were determined during the lifelong learning process.
\end{abstract}

Keywords: choir music, choir education, volunteer music education, lifelong learning, music education, sustainability in choir music

\section{Introduction}

Lifelong learning takes place at schools, at work in short in every field of society when lifelong learning is considered, it is not relevant to limit age, social status or education level. Therefore, it is proper to think lifelong learning as a process supported both by occupotional and social success of achieving knowledge and skills by individuals and society as well (MEGEP, 2006). According to Güleç, Çelik and Demirhan, lifelong learning means the education that individuals or communities receive with the demands or needs of formal, informal or distance education through formal, non-governmental organizations and private persons in order to provide acquire new knowledge and skills or develop existing knowledge and skills without the time, space and subject restriction in any phase of their lives. Turkey showed its emphasis to lifelong learning by managing its work from a single center and establishing the General Directorate Lifelong Learning under the roof of Ministry of Education (Güleç, Çelik, Demirhan, 2012). The European Union describes lifelong learning as the activities that aim to develop knowledge, skills and abilities of individu als society, professionally and individually. In the twenty first century, we experience information age and technology is changing and improving everyday. So, people are to pay attention to keep up with the change and personal development. Numerous technological equipment such as intelligent ventilation systems, self drive cars, comlex searching systems, tablet computers and intelligent watches are introduced everyday and lifelong learning is needed for people to keep up with these technological changes (Adabaş, Kaygin, 2006). Today's societies, where teaching is no longer limited to educational institutions, and life-long learning is a necessity, have had to re-question the needs of their individuals and society. In this context, individuals with lifelong learning skills were needed. Lifelong learning transforms the education and learning of individuals into a process at home, at work at a cafe etc. everywhere throughout life, instead of concentrating it in a certain part of their life. Lifelong learning also means to create a second opportunity for people through updating of basic skills and to offer further learning opportunities (Soran, Akkoyunlu, Kavak,2006).

According to Decree Law on the Organization and Duties of the Ministry of Education, issued 14 September 2011 and 28054 numbered Official Gazette National, some of the duties of the General Directorate of Lifelong Learning are as follows: "Establish policies, implement, monitor and evaluate policies to disseminate education and training in a lifelong manner other than compulsory education. Execute formal, informal and distance education. Provide general or vocational and technical education services for the citizens who have not entered the formal education system or have left or incompleted any educational level. To prepare education and training schedules, textbooks, educational tools and 
equipments of non-formal education and training schools and institutions to present them to the Board of Education and Training (Resmi Gazete, 2011). In the research titled "Higher Education and Lifelong Learning: A Model Proposal" which have submitted by Titrek, Güneş and Sezen in 2013, it is stated that especially Continuous Education Centers are in the first rank among "research and application centers" which are the beginning of the collecting service and lifelong learning existing in the Turkish Higher Education System. It is understood that the majority of these centers are related to "Language Education". All universities in Turkey need to establish Continuing Education Centers first among "research and application centers" .In a fast-globalizing world, this change has begun to reveal a type of human being who constantly renews the skills and knowledge, his needs to improve his competencies, especially in the course of the training of appropriate individuals. This situation makes it necessary to redefine the roles and functions of the education system. In addition to the technical and humanistic skills that individuals must possess, this rapid globalizing world has emerged as a need to have conceptual skills and to renew itself according to ever-changing world conditions. This has led to an increase in demand for higher education in which conceptual skills are gained more and higher education system to take a more active role. Moreover, with the qualifications gained by the skills gained with the diplomas taken from the higher education system, the process gives the chance to compete adequately in the whole of the business life. But, To keep in step with quick changes in both professional and social life, it happens to be an inevitable necessity for on individual to develop lifelong qualities (Titrek,Güneş,Sezen,2013).pportunities offered by universities in Turkey, promotes educational, professional and personal development of academics and help them to be a part of their lifelong learning process. Moreover, institutions and organizations providing services in a variety of non-formal education outside of universities in Turkey and has an important role in the development of this process. In this regard, a lot of establisments are taking initiatives such as facilities, ministries, local authorities such as provincial, district and district authorities, independent institutions such as the Presidency of Religious Affairs and the Turkish Radio and Television Corporation, professional associations such as trade unions and small business associations, voluntary organizations, Community centers, Red Crescent Society, Earth Erosion, Many organizations, such as the Turkish Foundation for Afforestation and the Protection of Natural Habitats (Haseki and Odabaş1, 2017). Poyraz and Titrek (2013) say that within the scope of lifelong learning it is not enough for an institution or an establishment alone to take responsibility and also it is emphasized that it has to become a life philosophy with the support of government, social media and municipal comparations in Turkey. İn their study, it is achieved as an important result to establish the culture of lifelong learning and to institute collaboration both in and among the institutions with this philosophy and to develop the idea with the support of coordination.

One of the main sources of lifelong learning is the broad media network offering "free choice" to the public and organizations supporting the increasing demand for learning by the public. This learning of the individual is often a voluntarily learning and in the direction of his own needs and interests [9].Technology-based learning and distance learning, and especially asynchronous learning over the Internet, have become important tools to meet the needs of lifelong learning (Beller, Or, 1998).

By year of 2017, Higher Education Credit and Dormitories Institution organizes educations, social-and cultural events and sports activities in order to strengthen national, spiritual, social, cultural, bodily, spiritual, mental and academic feelings, strengthen friendship and brotherhood ties and keep the students out off the addictions, bad habbits and bad behaviours. These activities are determined according to interests and abilities of the students by considering the physical structure of the dormitories. With these facilities, the activities and courses presented to the students it is aimed to develop themselves in different areas and they have to be involved in the lifelong learning process.

Schools have great impact in shaping the attitude toward lifelong learning of individuals. During the school years, individuals experience different learning styles thanks to several teachers. In fact, parents, grandparents play on efficient role in the development of manner in the philosophy of lifelong learning as well as schools. The factors playing role in shaping of lifelong learning philosophy represent different educational philosophies (Kaygin, Yilmaz, Semerci, 2017).

Nowdays, it is easy to access information as it is not limited with the education institutions and is given by various institutions and people. As a result, an individual, in interaction of knowledge, enters into the process of achieving lifelong learning ability.

The concept of lifelong learning is an important factor in the acceptance of a person in the society in which he lives, in economic terms as a qualified person in the labor market, psychological self-fulfillment, and an important driving force for the transfer of values and cultures (Çuhadar, Ünal, 2018). Lifelong learning is an educational concept that is very popular in western countries and is implemented by both national and international organizations. For that reason, lifelong learning skills, attitudes, and the education system itself provide a way to keep up with the pace of modern transformation (Murphy,1999).

Lifelong learning is a multidimentional concept. This concept can be used to organize all education and training that 
bring all skills and abilities to individuals and societies to be supported during lifespan. Lifelong learning includes learning strategies, achievement of knowledge, development of understanding attitude, volues. All these are necessary for moral peace. İn this constantly progressing age, personel development, social and economic welfare, cultural identity and employment (Walters, Yang, Roslander, 2014). We are exposed to learning involuntarily. A very simple example of this is that we are promoted to learn from social media and internet. We are encouraged to learn because of either sense of wonder or eagerness to learn.

So what ground does music have in one's life during the period of lifelong learning? With Which alternatives is it offered?

According to Uçan, the main purpose of music education is to provide the individual's cognitive, mental and emotional development. When appropriate training is given, music can have a very positive effect on the development of the individual. The objectives set out in this regard are; the development of listening ability of the person, the development of the perception skills through the sounds they listen to, and the social development (Uçan, 1994).

Music education is offered to individuals through formal and mass education. While music education given of schools is named as formal education, music education taught at various music institutions and organizations is titled as mass education. Amateur music education in mass education aims to teach individuals, who are enthusiastic in learning, necessary musical qualities for pleasure and satisfaction. The courses, concerts, festivals, compititions organized by these private institutions have on important role in amateur education (Uçan, 2005). Amateur music education is a kind of education that targets to achieve pleasure and satisfaction no matter one's abilities are and develop the level of on individual in accordance with the interest and wish (Ürün,2015). As mass education, there are many opportunities for individuals for oneself with alternatives such as instrument training, voice training and choir training in public education centers established to serve to public by government. İn private music organizations and in choirs made up with personal efforts. Individuals needed to learn from various reasons at every stage. For example, the main reasons for the orientation of young children to music education are thought to be the development of children in a social environment and personal development by being in a cultural environment. The findings from the parental view that music was chosen as a reinforcement type of education to support the mental development of the child in the study entitled "The Effect of the Polyphonic Choir Education on the Social Development of the Children" in 2015 (Kaynak, 2015).

Özmenteş say that Crafts, Cavicchi, Keil, Faulkne, Davidson, Gavin and Pitts have reported in their studies that the musical experiences of childhood and youth are influential and fundamental to the musical activities in adult and the subsequent periods. He examined that phases of music in 3 stages in the period of Lifelong learning. $1^{\text {st }}$ stage $=$ Prenotal adolescence 2 nd stage $=$ adolescence-adulthead $3^{\text {rd }}$ stage $=$ adulthead - elderliness $\left(\right.$ Özmenteş, 2017). $1^{\text {st }}$ stage $=$ Prenotal adolescence İn the first stage, children start to learn with games and are grown up with games. The more a game is crowded with children, the more a child enjoys. When to start music, it is better to have port in a polyphonic choir to enjoy and learn with his pears rather than to play on instrument. They learn to keep up with the group and the requirements needed with a choir training. Individuals will perceive music rules in the community by seeing and will become a musical discipline by hearing. Children get important gains in the lifelong learning process by participating in the chorus aside the volunteer education they have taken outside the school.

Children demonstrate various behaviours as the must precious achievements as well as they enjoy being in the choir during lifelong learning period. These achievements are the ones like going to concerts and attending several musical events.

İn the 2 nd and $3^{\text {rd }}$ stages, achievements do not differ from one another. For adults, musical events participated in by adults as amateur individuals serve them various opportunities and they improve themselves by having an education opportunity. At this stage, they learn to listen when listening to music or playing music, to pay attention and concentrate and to show respect. In order to get away from the stress of their business environment, individuals choose music for lifelong learning with an enthusiasm for self-development in e new field.

A study conducted in China emphasized that lifelong learning is more a trend of adults in recent years, especially those who have reached retirement age. There are several reasons. The first factor is to cope with the changes in the working life that caused rapid and radical shifts in economic and productive structures over the past decade; The second important influence is the combination of sophisticated new technology and today's market-driven economy, encouraging people to learn new approaches to personal and social life, which suggests that more middle-aged and older people need lifelong education (Zhang, Xu, 2015). Lifelong learning courses for older adults, especially those most vulnerable, have the potential to be an effective model of social care (Narushima, Liu, Diestelkamp, 2017).

According to Adams, the individual's participation in various musical activities and performances can lead to the development of one's individual and social identity (Adams, 2000). In the life-long learning process, the most preferred choirs in music are an education model that can influence societies in the most effective, most common, fastest and 
cheapest manner. With musical education taken in chorus and acquired musical work cultures, the individual learns to work consciously and carefully, learn to be programmed, develops in affective, dynamic and cognitive areas. By doing so, Koreans are able to become a beneficial individual who is social in society, to achieve cultural gains with the activities that they reveal, and to be an individual who shares their achievements with the society and communicates with society. On the stage for the concert performance, by revealing their self-confidence individuals exhibit their skills and experience to express theirselves well.

İn this study an answer to the question "What are the views of choir masters about the lifelong learning abilities of chorists?" is tried to be found out.

Sub problems of study:

1-What are the opinions of choir masters about the lifelong learning?

2-According to choir masters, what are the influences of choir training on the chorists?

3- According to views of choir masters, what are the achievements of chorists within the scope of lifelong learning?

\section{Method}

In general, 'Descriptive Method' was followed in the research. 'Document Literature Review Technique' was used to collect source data. 'Interview Technique' was applied to choir masters in order to reveal the impact of chorus on the individuals. Acquired data by using 'Interview Method' was interpreted and evaluated. Since this research enlightens the reaching sample group and plays an important role to navigate them to art, is in descriptive qualification status.

\subsection{Universal Sampling of Research}

The researchs universe is chorus chiefs and the sampling is the chorus chiefs which are educators in life-long learning institutions or are extrascholastic educators in volunteer choirs. When the sample group was determined, care was taken to choir masters who worked with people 55 to 70 and provides training for various musical genres like Turkish art, Turkish folk and polyphonic western music chorus for.

\subsection{Data Collection Tools}

This research is a qualitative research and the data was collected by means of literature review and the semi-structured interview form application methods required by qualitative approach. An interview form has been implemented to get opinions of chorus masters about the effects of chorus work on social development and personal development of the individuals they have participated in this process. The data obtained by the interview method was evaluated and interpreted. Each of the data obtained as a result of the interview is analyzed by content analysis method. Codes are tabulated and interpreted into numeric data.

\subsection{Data Analysis}

The semi-structured interview form was sent to 2 experts for triangulation method and was asked to evaluate the questions. The questions were evaluated by two experts in terms of content, language and comprehensibility. The experts were asked to score the questions. If the questions were adequate (3), if adequate but correction required (2) and if not enough (1). Scoring from two different experts is shown in the table below. The interview coding keys of the interview form applied to the choir chiefs and interviews logs were arranged by the researcher. Data analyzed by content analysis method were coded and transformed into numerical data and interpreted by evaluation of numerical data. In this research designed according to qualitative research approach, the data were analyzed in four stages: 1 . Encoding the data, 2. Determining the themes of the encoded data, 3. Editing the codes and themes, 4. Defining and interpreting the findings. During the analysis process interview records and written forms were decrypted and analyzed.

Table 1. Evaluation criteria for semi-structured interview forms

\begin{tabular}{l|l|l|l|l|l|l|l}
\hline Expert 1 & \multicolumn{3}{l|}{ Expert 1 } & Total \\
\hline Question & Language & Content & Comprehensibility & Language & Content & Comprehensibility & \\
\hline 1 & 2 & 3 & 3 & 3 & 3 & 3 & 17 \\
\hline 2 & 2 & 3 & 3 & 3 & 3 & 3 & 17 \\
\hline 3 & 2 & 3 & 3 & 3 & 3 & 3 & 17 \\
\hline 4 & 3 & 3 & 3 & 3 & 3 & 3 & 16 \\
\hline 5 & 2 & 3 & 3 & 3 & 3 & 3 & 17 \\
\hline
\end{tabular}

According to the results in the table, a semi-structured interview form, consisting of 5 questions, was formed by making necessary corrections on 5 items. Semi-structured interview form were sent to 4 expert core masters for reliability study. 
When preparing the structured interview forms open-ended questions were preferred in order to achieve the goal and determine the situation.

With these arrangements reliability formula, suggested by Miles and Huberman (1994) was applied to each question of semi structured interview form.

Formula 1: Miles and Huberman reliability formula

$$
\mathrm{R}(\text { Reliability ) }=\text { - Na ( concensus) }
$$

The answers obtained from the experts were evaluated one by one, calculated with the above formula and the results were shown in Table 2.

Table 2. Reliability results of answers of choir masters

\begin{tabular}{llll}
\hline Question & $\mathrm{n}$ & $\%$ & Evaluation \\
\hline 1 & 4 & 94,4 & Valid \\
\hline 2 & 4 & 94,4 & Valid \\
\hline 3 & 4 & 94,4 & Valid \\
\hline 4 & 4 & 88,8 & Valid \\
\hline 5 & 4 & 94,4 & Valid \\
\hline
\end{tabular}

\section{General Validity of the Scale $\% 93, \overline{28}$}

Since the reliability calculations are over $\% 70$, results are considered to be reliable for research (Miles and Huberman 1994). Results in this table and 5 questions in semi-structured interview form are considered reliable for this research.

\section{Findings}

\begin{tabular}{|c|c|c|c|}
\hline Options & $\mathrm{N}$ & Frequency & Total \\
\hline Yes & 1 & $(\% 20)$ & \\
\hline No & 4 & $(\% 80)$ & 5 \\
\hline
\end{tabular}

\subsection{Findings of Chorus Masters Opinions about Lifelong Learning}

Table 3. Chorus masters opinions about lifelong learning

One of the choir masters indicated that he was quite qualified on the subject, while the other 4 choir masters stated that they did not have detailed information with the theoretical life-time learning process but that they realized that the music education of the students was a direct factor in this process The chorus chefs, who teach volunteer music, are actively involved in direct lifelong learning. These studies, which are carried out by people from different professions and different age groups, provide different achievements to the choir chefs. In the lifelong learning process, both the choir chiefs and the chorists are developing in various subjects.

According to the statements of 3 choir masters; since the individuals in these groups have different levels of knowledge among themselves, they have simplified different teaching methods and created solutions instead of difficult technical aspects while running the work. In this case, the 3 choir masters emphasized that they had provided their own development by using different teaching methods in lifelong learning process.

\subsection{Findings on the Effects of Choir Education on Chorists According to Choir Chiefs}

As a result of inteviews with the core masters; the findings of the personal development, social development and musical development of the chorists were reached. Findings of the three steps are mentioned below. 


\subsubsection{Findings of the Personal Development of the Chorists}

Table 4. Codes regarding to personal development

\begin{tabular}{lllc}
\hline Codes & $(\%)$ Frequency & $\mathrm{N}$ & Total \\
\hline $\begin{array}{l}\text { Mental Therapy } \\
\text { Working discipline }\end{array}$ & 5 & $\% 100$ & \\
$\begin{array}{l}\text { Development of responsibility by regular attendance } \\
\text { sense of continuity }\end{array}$ & 5 & $\% 100$ & 14 \\
& 4 & $\% 80$
\end{tabular}

Many of the choir masters said. that chorists shared their preference for chorus music was for therapy in order to get rid of their spiritual troubles at the beginning. they are aware of the discipline that new information needs to be supported during individual hours with self study. According to the participants, the chorists take responsibility for the understanding of continuity by providing regular participation to the workshops, while gaining collective work discipline with choral music.

3.2.2 Findings about the Social Development of the Chorists

Table 5. Codes regarding to social development

\begin{tabular}{llrl}
\hline Codes & N & $(\%)$ Frequency & Total \\
\hline Socializing & 5 & $\% 100$ & \\
Self Satisfaction & 5 & $\% 100$ & 13 \\
Feeling Honored & 3 & $\% 60$ &
\end{tabular}

It has been observed that the hesitant individuals who are suffering from socialization are more active happier and sharing their ability to express themselves better as a result of the choir work They have expressed that many of the chorists are good listeners for a certain age, and they are satisfied with this kind of genuine music education opportunities.

Choir masters have emphasized that the most instructive part of choral work is in the staging. Individuals have said that they are honored with the applause they have received from their loved ones at the end of their performance and they experienced the excitement of the stage, especially individuals who sing solo.

\subsubsection{Findings Related to Musical Development of Chorists}

Table 6. Codes related to musical development of chorists

\begin{tabular}{lccr}
\hline Codes & N & Frequency (\%) & Total \\
& & & \\
\hline Proper breathing & 5 & $\% 100$ & \\
Effective and accurate speraking & 5 & $\% 100$ & 14 \\
Theoretical Knowledge & 4 & $\% 80$ &
\end{tabular}

As the chorus learns to breathe through the diaphragm differently than ever before when the chorus sings in singles or on their own, and the breathing is regular according to the phrases of the singing, the individual gains the ability to control breathing. Individuals have also learned to speak effectively and accurately while they learn to use their voice effectively and accurately. Rather than the rhythm and theoretical knowledge of studied in choir workshops, they emphasize the development of correct and beautiful speech skills as a result of the beautiful articulation of the words. The choir masters observed that individuals leaded their children, their grandkids, and the children in their surroundings to music by the satisfaction they received from their choir work. 


\subsection{Findings of the Benefits of the Chorists in Life-long Learning According to the Views of the Choir Masters}

Table 7. Coders regarding to Benefits of the Chorists in Life-long Learning

\begin{tabular}{lccc}
\hline Codes & $\mathrm{N}$ & Frequency(\%) & Total \\
\hline $\begin{array}{l}\text { Social development and personal } \\
\text { development }\end{array}$ & 5 & $\% 100$ & \\
$\begin{array}{l}\text { Using voice correctly and learning } \\
\text { to speak effectively }\end{array}$ & 4 & $\% 80$ & 30 \\
$\begin{array}{l}\text { A different point of view at life } \\
\text { from a from an artistic framework }\end{array}$ & 5 & $\% 100$ \\
$\begin{array}{l}\text { Harmony with the community and } \\
\text { supplying demands }\end{array}$ & 4 & $\% 80$ \\
$\begin{array}{l}\text { Quality of life by acquiring a social } \\
\text { environment }\end{array}$ & 3 & $\% 100$ \\
$\begin{array}{l}\text { Responsibility by participation in } \\
\text { the concerts }\end{array}$ & 5 & \\
$\begin{array}{l}\text { Improvement for self-confidence } \\
\text { with stage performances }\end{array}$ & & \\
\hline
\end{tabular}

As a result of the interviews, choir masters stated that individuals aged between 55 and 70 participated with enthusiasm and willingness to work because they want to study music but they could not find a chance for that during their lifetime. They expressed that the individuals, to whom behavior and talent requirements of the choral music submitted, had no trouble getting to know it because of their conscious and enthusiastic approach.

All of the choir masters summarized the will the chorists should be included in the lifelong learning process in two items. The first stated that the chorists participated in these activities in order to provide their own personal development and the second stated that they participate to improve their knowledge skills and competences by socializing.

\section{Results, Conclusions and Recommendations}

Choir education is a cultural education that has an impact on the individual's musical development as well as his social, cultural and psychological life. According to Sarıçiftçi, because the music is a universal language, the choruses ensure that the societies with different languages, religions and traditions become closer and closer to each other. Choruses are places which have great benefits for communities and individuals and where human love is integrated. The importance that music has in the education, cultivation and personality of the individual is an undeniable fact. For that reason, it is emphasized to attach importance to choral tradition and its widespreadness in a society and the necessity of establishing the sub-structures of children, youth and adult choruses and ensuring continuity for chorus tradition (Sarıçiftci, 2001).

In this research, chorus chiefs observed that the chorists found the best examples of friendship and solidarity in these communities, found mutual love and respect. They experience responsibility, happiness and occasionally sadness. All the rules of a democratic life are available in the choir. Everyone is able to tell their own feelings and thoughts in certain rules, to listen to someone else and to learn better to be a useful person for himself and his family.

In this research, individuals who are subject to the lifelong learning process with chorus education have achieved the following benefits by providing regular participation to the workshops.

Choir masters stated that choir education for individuals; improves social development and personal development,

provides a different point of view at life from a from an artistic framework, provides adaptation to the community, provides harmony with the community and supplying demands, strengthens the quality of life by acquiring a social environment, provides musical discipline by perceiving and hearing music rules in the community, teaches to listen carefully. Saklica in his study regarding to achievements of chorus education to the individuals concluded that in the chorus, together with breathing habit towards the individual, relaxation, vigilance, consciousness is achieved for physical and mental preparation, improves the musical sensitivity (musicality) of the individual, thereby achieving effective voice-interpretation skills by improving loud and clear and lucidness qualities in the speech language , by articulating tongue and voice-quiet phoneme in singing language and by using intonation and emphasis correctly (diction Saklica, 2010). 
In this study, the result of which the chorists learned the right breath and to use the diaphragm breath, which are the requirements to sing provides to know own voice, using voice correctly and learning to speak effectively, provides musical theoretical knowledge (note reading skill), provides to think aloud with polyphony, provides taking responsibility by participation in the concerts and duties given, provides improvement for self-confidence with stage performances.

After a concert with a successful praise, they shared with the chorus chefs that they are more motivated and committed to continuing this education. This result agrees with Yilmaz and Kaygin that life-long learning and motivation in their research have a crucial role in promoting success and motivation in people's lives throughout their lives (Y1lmaz, Kaygin, 2018). Gokce in his A General Review on Benefits of Turkey Choirs Festival With Regard to Social Functions of Choral Musi. observes the significant impact of the achievements gained by choral music on the success in professional lives of amateur choir members (Gökçe,2007).

\section{References}

Adabaş, A., \& Hüseyin, K. H. (2016). Lifelong Learning Key Competence Levels of Graduate Students, Universal Journal of Educational Research 4(12A), 31-38.

Adams, K. (2000). How can I keep from singing: A lifetime of sweet singing in the choir. In B. A. Roberts \& A.Rose (Eds.), The phenomenon of singing (2): Sharing the voices. Proceedings of the international symposium St John's, Newfoundland, Canada 1999 (pp. 7-15). St John's, Newfoundland: Memorial University of Newfoundland.

Beller, M. (1998). The Crossroads between Lifelong Learning and Information Technology a Challenge Facing Leading Universities. Journal of Computer-Mediated Communication, 4(2), 1 December.

Crafts, S. D., Cavicchi, D., \& Keil, C. (1993). My music. Hanover, MD: Wesylan University Press.Çuhadar E., Ünal F.,2018, Evaluation of Contribution of Local Newspapers to Lifelong Learning (Example of Bartın Province), Universal Journal of Educational Research, 6(3), 478-490.

Faulkner, R., \& Davidson, J. (2004). Men's vocal behaviour and the construction of self. Musicae Scientiae, 8(2), 231-255. https://doi.org/10.1177/102986490400800206

Gavin, H. (2001). Reconstructed musical memories and adult expertise. Music Education Research, 3(1), 51-62. https://doi.org/10.1080/14613800020029950

Gençlik ve Spor Bakanlığı, Kredi ve Yurtlar Kurumu Eğitim faaliyetleri, http://yurtkur.gsb.gov.tr/Sayfalar/2418/2387/EgitimFaaliyetleri Erişim Tarihi 16.05.2018

Gökçe, M. (2007). Koro Müziğinin Toplumsal İşlevleri Açısından Türkiye Korolar Şenliğinin Kazandırışları Üzerine Genel Bir Değerlendirme. Uluslararası Asya ve Kuzey Afrika Çalışmaları Kongresi (ICANAS'38) 10-15 Eylül 2007, Ankara. Atatürk Kültür, Dil ve Tarih Yüksek Kurumu Başkanlığı, 1(1), 325-352.

Güleç, İ., Çelik, S., \& Demirhan, B. (2012). Yaşam boyu öğrenme nedir? Kavram ve kapsamı üzerine bir değerlendirme. Sakarya University Journal of Education, 2(3), 34-48.

Haseki, H. İ., \& Odabaşı, H. F., (2017). Positions and Preferences: Faculty Goes for Lifelong Learning, a View from Turkey International Journal of Higher Education, 6(6).

Kaygin, H., Yilmaz, E., \& Semerci, Ç. (2017) The Relation between Lifelong Learning Tendency and Educational Philosophies, Universal Journal of Educational Research 5(12A), 121-125.

Kaynak, T., (2015). Çocukların Sosyal Gelişiminde Çoksesli Koro Eğitiminin Önemi 11th International Congress of Qualitative Inquiry (Basılmamış bildiri). İllinois Üniversitesi, Urbana, America

Lundmark, C. (2002). Lifelong Learning. BioScience, 52(4), 1 April 2002, Pages 32. https://doi.org/10.1641/0006-3568(2002)052[0325:LL]2.0.CO;2

Mesleki Eğitim ve Öğretim Sisteminin Güçlendirilmesi Projesi (MEGEP). (2006). Türkiye'nin başarısı için itici güç: Hayat boyu öğrenme politika belgesi. Ankara.

Miles, M. B., \& Huberman, A. M. (1994). Qualitative data analysis. America: United States of America Printed.

Murphy, T. F. M. (1999). Power and knowledge in education: A critical exploration of lifelong learning. Doctoral Dissertation.Northern Illinois University, Illinois.

Narushima, M., Liu, J., \& Diestelkamp, N. (2017). I Learn, Therefore I am: A Phenomenological Analysis of Meanings of Lifelong Learning for Vulnerable Older Adults, The Gerontologist cite as: Gerontologist, $00(00), 1-10$.

Özmenteş, G. (2017). Eğitim ve Öğretim Araştırmaları Dergisi Journal of Research in Education and Teaching Mayıs, $6(2)$. 
Pitts, S. (2009). Routes and roots in adult musical participation: Investigating the impact of home and school on lifelong musical interest and involvement. British Journal of Music Education, 26 (3), 241-256. https://doi.org/10.1017/S0265051709990088

Poyraz, H., \& Titrek, O. (2013). Türkiye'de Hayat Boyu Öğrenmenin Geliştirilmesi, Abant İzzet Baysal Üniversitesi Eğitim Fakültesi Dergisi, 13(1).

Resmi, G. (2011). Milli Eğitim Bakanlığının Teşkilat ve Görevleri Hakkında Kanun Hükmünde Kararname, sayı: 28054, 14 Eylül 2011.

Saklıca, E. (2010). Bireysel Ses Eğitiminde Toplu Ses/Koro Eğitimine Geçiş Sürecindeki Yaklaşımlar, Afyon Kocatepe Üniversitesi Sosyal Bilimler Enstitüsü Müzik Anabilim Dalı Yüksek Lisans Tezi 187.

Sarıçiftçi, A. Ö. (2001). Toplu Ses Eğitiminde Entonasyon Sorunu ve Çözümünde Uygulanacak Yöntemler, Pamukkale Üniversitesi Sosyal Bilimler Enstitüsü Güzel Sanatlar Anabilim Dalı. Yüksek Lisans Tezi 54.

Soran, H, Akkoyunlu, B., \& Kavak, Y. (2006). Yaşam Boyu Öğrenme Becerileri ve Eğiticilerin Eğitimi Programı: Hacettepe Üniversitesi Örneği. H.Ü. Egitim Fakültesi Dergisi, 30, 201-210.

Titrek, O., Zafer, G. D., \& Sezen, G. (2013). Yükseköğretim ve Yaşam Boyu Öğrenme: Bir Model Önerisi. ICQH 2013, 12-14 Aralık 2013, Sakarya Üniversitesi Kongre ve Kültür Merkezi.

Uçan, A. (1994). Müzik Eğitimi Temel Kavramlar-İlkeler-Yaklaşımlar, Müzik Ansiklopedisi Yayınları, Ankara Uçan, A. (2005). Müzik Eğitimi. Ankara: Evrensel Müzikevi.

Ürün, T. (2015). Karşılaştırmalı Tonal ve Makamsal Dizi Öğretiminin Silahlı Kuvvetler Bando Okulları Öğrencilerinin Bilişsel Gelişimlerine Etkisi. Yüksek Lisans Tezi: Afyonkarahisar.

Walters, S., Yang, J., \& Roslander, P. (2014). Key Issues And Polıcy Consıderatıons In Promotıng Lifelong Learnıng In Selected African Countries 11 Ethıpıa, Kenya, Namıbıa, Rwanda And Tanzanıa Unesco Institute For Lifelong

Yilmaz, E., \& Kaygin, H. (2018). The Relation Between Lifelong Learning Tendency and Achievement Motivation Journal of Education and Training Studies, 6(3a), March 2018

Zhang, M., \& Xu, J. (2015). The Role Of Universities In Elder Education: The Experience Of Shangha1 And Shangha1 Normal University, Unesco Institute for Lifelong Learning, The Role of Higher Education in Promoting Lifelong Learning, 129.

\section{Copyrights}

Copyright for this article is retained by the author(s), with first publication rights granted to the journal.

This is an open-access article distributed under the terms and conditions of the Creative Commons Attribution license which permits unrestricted use, distribution, and reproduction in any medium, provided the original work is properly cited. 